\title{
CURRENT STATUS AND SOLUTIONS TO REDUCE LOGISTICS COSTS IN VIETNAM
}

\author{
Nguyen Hoang Phuong* \\ Regional Political Academy 2, Ho Chi Minh city, Vietnam \\ *Corresponding Author E-mail: nghoangphuong11@gmail.com
}

This is an open access article distributed under the Creative Commons Attribution License, which permits unrestricted use, distribution, and reproduction in any medium, provided the original work is properly cited.

\section{ARTICLE DETAILS}

\section{Article History:}

Received 13 July 2019

Accepted 15 August 2019

Available online 27 August 2019

\begin{abstract}
Currently, Logistics is a tremendous economic resource for each country. Logistics knows as an economic activity organized by businessmen at one step or different steps including Receiving goods, shipping, warehousing, customs clearance, customer consultation, packaging, delivery, and other goods related services to receive remuneration. In recent years, liberalization in trade and international economic integration has made the demand for exchanging and buying goods globally already higher. In such a context, logistics cost will affect to compete of goods. So, the activity that was reducing logistics cost is necessary. It helps the cost decreasing export cost, increasing the competition of goods. Nowadays, logistics cost in Vietnam higher than logistics cost in the world average, so how to reduce logistics cost to increase competition of goods? It is a problem that needs to be solved in Vietnam's enterprise.
\end{abstract}

KEYWORDS

Logistics costs, economic integration, solutions.

\section{INTRODUCTION}

Logistics is a circle that includes activities such as storage of goods, packaging, packaging, warehousing, goods circulation, customs clearance ... to achieve the ultimate goal of product and goods transfer [1]. From suppliers to consumers in the most optimal way [2]. From this point of view, Logistics staff will be in charge of the work related to the series above of activities [3]. If doing well Logistics, businesses will save a small transportation cost, which means that the cost of products will be lowered, thereby improving competitiveness and bring more profits [4].

Logistics cost is the term for using different resources, including human resources, goods, money, information to perform customer care services and is calculated by the amount of money consumed [5]. When attached to commercial shipping lines, logistics costs are expressed as the amount of money spent on the service delivery system, after-sales, goods supply, and production management [6]. Low logistics costs will significantly contribute to trade facilitation, creating added value, and improving the competitiveness of import and export goods. The logistics cost index evaluates the level of development of a country's trade. For example, the percentage of logistics costs in GDP of some countries: Australia about 9\%, Brazil, Mexico 15-17\% (1), Thailand 19\% (2005) (2), Europe 12\% (20062008) and China 21.3\% (2004). Vietnam estimates are 20-25\% [7]. Logistics is a chain of integrating many economic activities to optimize the position and transport process, stockpiling goods from the beginning to the end of consumers[8]. Therefore, to manage logistics is to analyze the total cost [9]. It is understood that for customer service, managers must find ways to reduce costs to the lowest level. The methods to calculate logistics costs are different and depend on the type and field of business of each business [10]. In general, logistics costs are expressed through the selling price of a commodity, and the formula is expressed as follows:

$\mathrm{G} \geq \mathrm{C} 1+\mathrm{C} 2+\mathrm{C} 3+\mathrm{C} 4+\mathrm{C} 5$

Inside:

G: The selling price of goods

C1: Production cost of goods. This is the basis for determining selling prices

C2: Marketing operation costs

C3: Transportation costs

C4: Capital opportunity cost for inventory

C5: Cost of preserving goods.
Thus logistics costs include C3, C4, C5 in the cost of a product. Therefore, the formula to calculate logistics costs is as follows:

$\mathrm{Clog}=\mathrm{C} 4+\mathrm{C} 5+\mathrm{C} 6$

\section{ANALYSIS OF LOGISTICS COSTS}

\subsection{Transportation costs}

Cargo transportation is the movement of goods in space to satisfy the demand of trading, to exchange goods by human power or to utilize means in the process of production - business - distribution of goods. In this process, freight transportation is like a thread linking production and business operations in different localities. Freight transport accounts for a large proportion - one-third to two-thirds of the cost of distribution[11] Although the transport sector has made efforts to reduce transportation costs by technological solutions such as container freight transport, building new vehicles, large-capacity equipment, multi-modal transport organizations, ... however, transportation costs are constantly increasing due to escalating fuel prices. This forces manufacturers to take many measures to reduce transportation costs. One of these solutions is to increase the ability to use equipment, tools, and means of transport by designing products, packaging goods to increase the density of goods. However, the relationship between cost and transport quality is always negative. To be able to meet the needs of customers (goods are present at the right time, in the right place, safely preserved, goods are not damaged, ...), they must be transported in small quantities but must ensure interoperability [12]. Continuous and with significant shipping frequency. Moreover, so, transportation costs in particular and logistics costs and product costs will increase. Therefore, managers must balance between these two types of indicators in order to ensure that the goods and costs are lowest.

\subsubsection{The capital opportunity cost for inventory}

This type of cost is the minimum rate of return that a company earns when capital is not invested in inventory but for another activity. For simplicity, we assume that the minimum rate of return for capital is the interest rate charged when borrowing from a financial institution, so this type of cost is determined as follows:

$C_{4}=\left(q_{i} \cdot k_{v}\right) t[(1+r) t-1]$ 
Inside:

- $\mathrm{q}_{\mathrm{i}}$ : number of products for one shipment

- $\mathrm{k}_{\mathrm{v}}$ : The norm of capital for a product unit. This level of capital depends on production technology

- $t=1 \div \mathrm{m}$ : number of time units subject to an annual interest rate of inventories (month or year)

- $r$ : interest rate payable for loans.

Through the formula, we see the opportunity cost, which depends on the capital market $(\mathrm{r})$, production technology $\left(\mathrm{k}_{\mathrm{v}}\right)$, and the volume of materials and products stored. If fixed $\mathrm{r}$ and $\mathrm{k}_{\mathrm{v}}$ are fixed, $\mathrm{C} 4$ is proportional to qi when qi is small how many times $\mathrm{C}_{4}$ is small and vice versa. Previously, when the market was still limited, the number of products produced was low, the interest rate was still low, so producers were less interested in this. Today, when the market is expanded, the number of products is high, the interest rate is high, this cost accounts for a significant portion of the total costs related to inventory. This forces manufacturers to have appropriate solutions to reduce this cost. Moreover, that solution is to reduce the volume for a turn of production and delivery (qi) down.

\subsubsection{Cost of preserving goods}

The cost includes the cost of renting a warehouse, preserving goods, bringing goods into and out of the warehouse, damaged goods, insurance for goods. The following formula represents warehouse costs:

$\mathrm{C}_{5}=\mathrm{q}_{\mathrm{i}} \cdot \mathrm{T}_{\mathrm{bq}} \cdot \mathrm{g}_{\mathrm{lk}}+\mathrm{q}_{\mathrm{i}} \cdot \mathrm{k} \cdot \mathrm{g}+\mathrm{C}_{\mathrm{bh}}$

Inside:

- qi: number of products for one shipment

- $\mathrm{T}_{\mathrm{bq}}$ : storage time in the warehouse of qi shipment

- glk: average cost for a unit of goods stored a day

- k: loss rate, inventory damage

- $\mathrm{g}$ : the value of the inventory unit

- $\mathrm{C}_{\mathrm{bh}}$ insurance costs for storage shipments

The cost of preserving goods to ensure the flow of goods takes place continuously. Types of expenses such as warehousing, storage of goods, ... ensure warehouse operations are going smoothly. Warehouse management costs are directly proportional to the number of goods in stock, and the volume of warehouses affects customer service. According to the above formula, we see that cost $\mathrm{C}_{5}$ is related to qi; If qi is small, the storage time is short, resulting in this small cost, and vice versa if large qi, the storage time of ti will be large, leading to a large storage cost of goods in storage.

\section{CURRENT STATUS OF LOGISTICS COSTS IN VIETNAM}

Logistics costs in Vietnam are much higher than in the world. In the ASEAN region, some countries such as Thailand, Singapore have reduced logistics costs, while Vietnam's costs are still at a high level, a barrier to competitiveness. According to the World Bank (WB), logistics costs (transportation, storage, customs clearance ...) in Vietnam are about 20.9$25 \%$ of GDP. This cost is $6 \%$ higher than Thailand, $12 \%$ in Malaysia, and 3 times higher than in Singapore [13]. According to the International Monetary Fund (IMF), average logistics costs account for $12 \%$ of the world's gross domestic product. In the US economy, logistics costs account for $9.9 \%$ of the country's GDP ( 921 billion USD in 2000). For businesses, logistics costs vary from $4 \%$ to over $30 \%$ of revenue. Particularly in Vietnam, logistics costs account for about $25 \%$ of Vietnam's GDP, of which transport accounts for about 50\% $-60 \%$, too high compared to the world. So what is the reason why Logistics costs in Vietnam are so high?

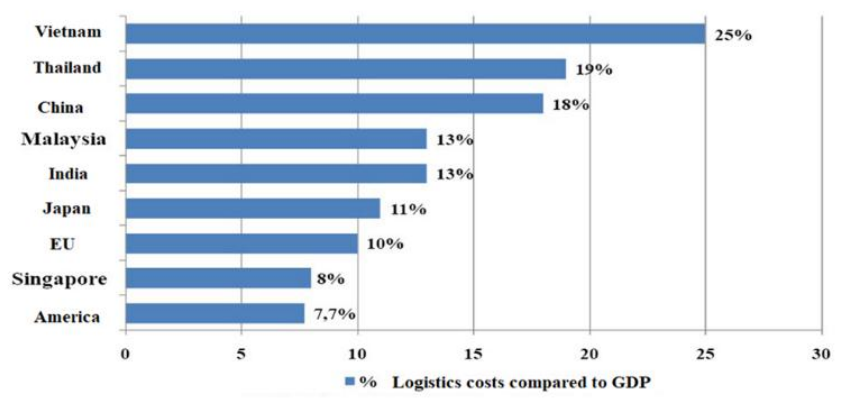

Figure 1: Logistics costs in regions and Vietnam [14]

Currently, many companies in Vietnam have not taken full advantage of logistics; even some enterprises have not seen the very important role of logistics in reducing production and business costs. Logistics has strong links between marketing, production, inventory, transport, and distribution. However, many companies arrange transport functions in the administrative office; inventory management is in the accounting - finance department, while the purchasing function is directly under the marketing department or sales ...[15] The organization discrete function rooms such that businesses manage these functions are also discrete. Therefore, it is necessary to form a separate component for logistics/supply chains so that department managers can coordinate closely with other functions.

In Vietnam, goods have to go through too many intermediaries, from the supply of raw materials to production, to the distribution of goods to consumers, increasing transaction costs, increasing selling prices [16]. In this series, all parties try to profit for themselves, and because of the lack of information, the members of the chain only know to have a direct relationship with their businesses without knowing the other members, it inflates logistics costs. On the other hand, the distribution system focusing on urban areas is mainly, but neglecting rural areas. The distributor is only responsible for short-distance transport and agents must take care of their transport problems. Moreover, the layout of the retail network is relatively dense in urban centers, while large warehouses are too far away, and because most businesses are not aware of the role of each. Warehouse types such as primary, secondary, and central warehouses should result in either low transport costs but high or vice versa costs of holding inventory, which either increases the total logistics fee [17]. Another concern is that businesses are not used to using outsourced services such as customs clearance agents, accounting agents, and 3PL outsourced services - which are mostly self-employed. When self-service businesses, investing in building warehouse racking systems or purchasing transport vehicles will need a lot of investment capital and challenging to reach the professional level. While the exploitation capacity is low, so the capital recovery is slow, inefficient, and the logistics cost is high.

\subsection{Infrastructure is still poor}

The quality of Vietnam's transport network is not synchronous at present, where technical standards do not ensure safety in traffic. Although there are 266 seaports, only 20 seaports can participate in the export of foreign goods. Most of these ports cannot receive commercial container ships because of faulty equipment and experience in container handling. In terms of transport modes, air transport is not yet accessible, but mainly by road transport [18]. However, as stated, this transportation system cannot be used for heavy cargo transportation by narrow roads, the technical quality is not high, and the transport capacity is too low, the traffic jam situation is often occurring. Many industrial parks have been built, but no roads or industrial zones have been located too far from the seaport system, leading to increased freight costs. Current railway transport only carries passengers mainly. With two different gauge systems $(1000 \mathrm{~mm}$ and $1435 \mathrm{~mm}$ ), this vehicle cannot be used to transport high-volume cargo and takes much time (the North-South railway takes 32 hours). Water transport is mainly by barge, low cost, safe, little accident, but a long time of transport and customers are not interested in this form of transportation.

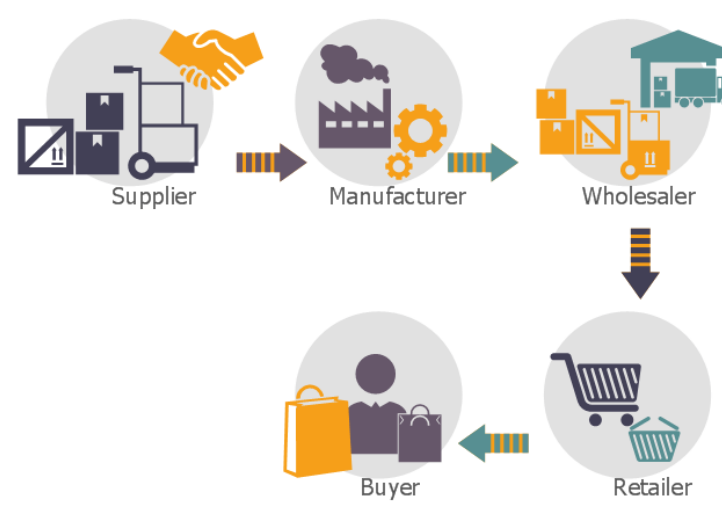

Figure 2: Activities in Logistics circle[19]

Also, the combination of different modes of financing (multimodal transport) to combine the advantages of each mode of transport is not common in Vietnam. For these reasons, the high logistics costs (mostly transport costs) are natural. This situation leads to very different retail prices across the country. A general trend of Vietnamese enterprises (and exporters in particular) is not to take risks. Therefore, the selling price of goods is based only on FOB origin, which is sold from the factory. However, excluding transportation costs, meanwhile, for comparable retail prices across the country. It is necessary to apply the FOB price, the price of goods plus the average transport cost from where to sell to customers' warehouses, so that landed costs are the same. 


\section{THE SOLUTION TO REDUCING LOGISTICS COSTS IN VIETNAM}

\subsection{Reduce transportation costs in logistics}

Transportation costs make up the majority of logistics costs. For example, Thailand in 2006, transport costs were 49\%, the United States in 2011 was $62.8 \%$, and Vietnam was about $60 \%$. Transportation is the most important economic activity in logistics activities. About $1 / 3$ to $2 / 3$ of the logistics costs of businesses are transportation costs. Therefore, cutting down transportation costs is essential in reducing logistics costs. However, there is a close relationship between transportation costs and effective inventory costs. Transportation costs depend on time, distance, and value, the volume of goods and supplies - goods with small volume, low value, low transportation costs. Also, the distance and location of cargo depots, as well as distribution centers compared to the place of production, also determine transportation costs. Transportation plays an essential role in improving the quality of logistics services and competitiveness of manufacturing businesses as well as import-export businesses because it transports goods and supplies to the right place that customers need them and on time with the lowest cost. The best service and the lowest cost for customers is the goal of commercial logistics. Without a fully developed transport infrastructure system, logistics operations in general and transport activities, in particular, cannot adequately promote their superiority. Therefore, the improvement of transport infrastructure system plays an essential role in lowering freight costs. Choosing the appropriate transport method, a leading job of logistics service providers, is also a factor in reducing transportation costs. Out-sourcing to utilize the professionalism of logistics service providers will contribute to reducing transportation costs. The total transportation cost includes the initial transportation cost (the cost of transporting finished goods from the factory and wholesalers to the warehouse) and subsequent transport costs (the cost of transporting finished products to consumers). Transportation costs in trade logistics costs include the total cost of the carrier of modes of transport, including road, rail, waterway, pipeline and inland transport and international transport. Air cargo as well as labor costs and costs related to shippers.

Currently, about $90 \%$ of our country's import and export goods are transported by sea; Road transport accounts for about $75 \%$ of domestic transport goods. Outsourcing of transport is also underdeveloped. The linkage of transport modes is also weak. Multimodal transport has not yet developed. Freight rates are not competitive. The quality of transport services has not met the requirements of customers on time. These are the salient features of our transport operations that need attention during the research process and learn more to reduce transportation costs.

\subsection{Professionalization of human resources}

Currently, many Vietnamese companies have not taken full advantage of the logistics provided, even enterprises (businesses) have not seen the critical role of logistics in reducing production and business costs. In about 1,000 logistics enterprises today, the forwarding enterprises are mainly, there are no real logistics enterprises, creating the system linkage as foreign enterprises are doing. Vietnam has about 1.5 million workers working in logistics. In particular, Ho Chi Minh City economic locomotive accounts for about $40 \%$, equivalent to 600,000 workers. The supply of human resources for logistics sector only meets about $40 \%$ of demand, while the average growth rate of the logistic industry increases by $20-25 \%$ annually. According to a survey by the Ho Chi Minh City Development Research Institute on logistics human resource quality, $53.3 \%$ of enterprises lack staff with professional qualifications and logistics knowledge, $30 \%$ of enterprises have to retrain. And only $6.7 \%$ of businesses are satisfied with their expertise.

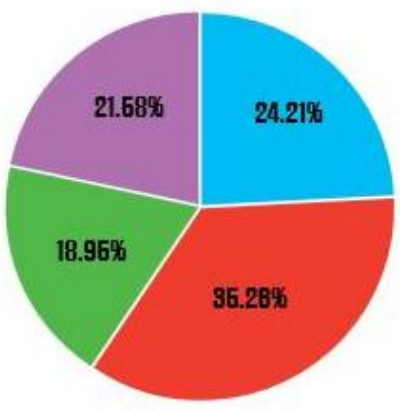

Lack of high quality human resources

Professionalism of human resources is low

Universities do not have a logistic training major

There is no title of logistics department in enterprises

Figure 3: Survey results on human resource constraints of the Vietnam Logistics industry
Experts in logistics industry said that Vietnamese enterprises today, in terms of scale are still tiny, except for a few dozen state-owned enterprises and shares are relatively large, the rest are a few types of equipment, facilities and infrastructures are still inferior, mainly buying and selling sea freight, air freight, agency clearance, and truck services ... The operation is not synchronous, fragmented, not professional, so it is slow to collect a return on investment, high cost.

\subsection{Synchronous traffic planning}

In Vietnam, goods must go through too many intermediaries, from the supply of raw materials to production, to the distribution of goods to consumers, increasing transaction costs, increasing selling prices. In 2011, logistics costs were estimated at over \$ 25 billion. One of the reasons leading to high logistics costs is because businesses only pay attention to transporting goods by road without being interested in waterways and airways, Mr. Thai Van Chung, General Secretary of Transport Association Ho Chi Minh City cargo loading, said that domestic transport infrastructure had not created a complete and strong system, linking provinces and regions to exploit its strengths. Also, many industrial parks are completed, but no roads or industrial zones are located too far from the seaport system, causing the cost of transporting goods to increase. Besides, the combination of different modes of transport (multimodal transport) to combine the advantages of each mode of transport is also not popular in Vietnam. For these reasons, the total logistics fee (mostly transport costs) is very high.

\subsection{Applying 5PL model}

5PL is the type of e-commerce market services, including 3PLs and 4PLs, and adds many upgrades in the value chain process, in which:

- 3PL is an outsourced logistics service, provided by a third party, but served separately

- $4 \mathrm{P}$ is a third-party logistics chain that provides a full range of services and solutions

- 5PL: Including 3PL and 4PL, adding many other factors to e-commerce. $5 \mathrm{PL}$ is also known as e-logistics and logistics for e-commerce.

The 5PL model adds three systems (Order Management System (OMS), Warehouse Management System (WMS) and Transport Management System (TMS). All of which are closely related to each other in the same unified system and combining information technology to provide the optimal solution and the interface for e-commerce. Based on the information of supply and demand in the market to coordinate and operate the supply chain for e-commerce. The 5PL model is effective in managing supply chains for SME businesses by optimizing costs, time and minimizing inventory requirements, reducing cost pressures, and competition. This model comes from the requirements of e-commerce 4.0 when online shopping has been developing very actively, recorded. Chinese e-commerce floors, particularly Aliexpress international wholesalers, have applied this for a long time. The reason that Chinese sellers have many advantages at a price compared to Vietnamese sellers is that they benefit from the dropshipping model in coordination with Aliexpress 5PL service and ePacket. International shipping costs on Aliexpress are usually cheaper than domestic shipping due to the advantage of ePacket. If ordering fast-charging products in China, domestic delivery will cost $\$ 3.04$ from ePacket, but this fee is very low or free if transferred to Vietnam or other countries. Therefore, Chinese sellers bear less pressure on logistics costs when cross-border sales are analyzed above. In contrast, Vietnamese sellers have been burdened with a lot of domestic and international costs such as: transporting goods from China to Vietnam, labor fees for counting, sorting, packing goods, and fees. Domestic transportation of Vietnam... Increasing cost pressures force Vietnamese sellers to deal with many different ways but create many difficulties and barriers such as:

- Non-official imports may face risks such as being held by the customs, managing the stock market due to the absence of import documents - Importing large quantities to save the cost of importing goods is very limited, if not selling goods, there will be many other costs such as storage, management, not including lost goods, damaged in time goods waiting for a sale.

Therefore, the best solution for Vietnamese sellers is to apply the 5PL service model to solve the current problem, reducing most of the pressure on costs and competitiveness. 
3Pl

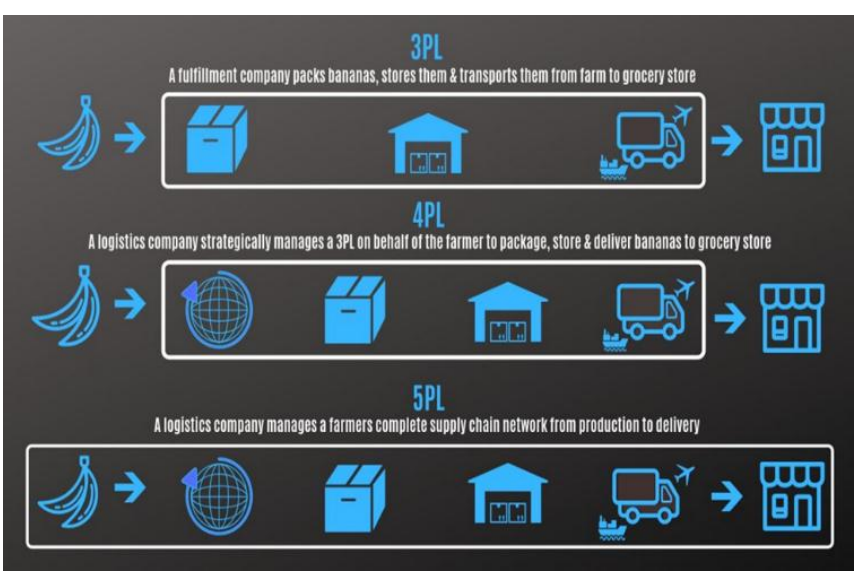

Figure 4: 5PL model [20]

\section{CONCLUSION}

Logistics services (warehousing, transportation, cargo procedures) are an indispensable stage to bring products and goods from production to consumers. According to calculations, Vietnam's logistics costs are high, accounting for nearly $25 \%$ of GDP, directly affecting the cost of products and competitiveness of enterprises. Logistics costs accounted for a large proportion are in danger of burdening business performance, reducing the competitiveness of the economy. Enterprises need to cut unnecessary procedures immediately. For localities, it is necessary to plan and use the appropriate land fund to build port distribution and logistics service center, connect conveniently with national transportation network, ICDs, and step by step create into logistics infrastructure network. Enterprises need to actively apply modern technology in the trend of forming the logistics industry in the industrial revolution 4.0 to enhance competitiveness, quality, and reduce service charges. Associations need to be linked between goods owners and enterprises providing logistics services, creating a basis for Vietnamese logistics enterprises to participate in many stages in the supply chain with increasing valueadded. In addition to raising awareness of logistics ministries, agencies, and localities, the Government will issue a Logistics Directive, aiming to bring Vietnam logistics to develop a regional and world level. The state will play a supporting role and create a favorable environment to improve competitiveness and develop logistics services.

\section{REFERENCES}

[1] Shin, Y.J., Oh, J.S., Shin, S.H., Jang, H.L. 2018. A Study on the Countermeasures of Shipping and Port Logistics Industry in Responding to the Progression of Fourth Industrial Revolution, J. Korean Navig. Port Reserch, 42(5), 347-355.

[2] Adewole, A., Struthers, J.J. 2018. Logistics and Global Value Chains in Africa: The Impact on Trade and Development. Springer.

[3] Bukova, B., Brumercikova, E., Cerna, L., Drozdziel, P. 2018. The Position of Industry 4.0 in the Worldwide Logistics Chains, LOGI-Scientific J. Transp. Logist., 9(1), 18-23.

[4] Jahn, C., Kersten, W., Ringle, C.M. 2018. Logistics 4.0 and sustainable supply chain management: innovative solutions for logistics and sustainable supply chain management in the context of industry 4.0 , in Hamburg International Conference of Logistics (HICL).
[5] Bouzon, M., Govindan, K., Rodriguez, C.M.T. 2018. Evaluating barriers for reverse logistics implementation under a multiple stakeholders perspective analysis using grey decision making approach, Resour. Conserv. Recycl., 128, 315-335.

[6] Massard, G., Leuenberger, H., Dong, T.D. 2018. Standards requirements and a roadmap for developing eco-industrial parks in Vietnam, J. Clean. Prod., 188, 80-91.

[7] Tran, T.T.H., Luc, T.T.H. 2018. Reverse Logistics in Plastic Supply Chain: The Current Practice in Vietnam, in Nachhaltige Impulse für Produktion und Logistikmanagement, Springer, 219-233.

[8] Ivanov, D. Tsipoulanidis, A. Schönberger, J. 2019. Digital Supply Chain Smart Operations and Industry 4.0, in Global Supply Chain and Operations Management, Springer, 481-526.

[9] Pham, V.V. 2018. Analyzing the effect of heated wall surface temperatures on combustion chamber deposit formation, J. Mech. Eng. Res. Dev., 41(4), 17-21.

[10] Wang, C.N., Nguyen, H.K. 2017. Enhancing urban development quality based on the results of appraising efficient performance of investors-a case study in Vietnam, Sustainability, 9(8), 1397.

[11] Nguyen, T.T. 2016. An Investigation of the Vietnamese Shipping Industry and Policy Recommendations for Profound Participation into ASEAN Integration, Asian J. Shipp. Logist., 32(2), 81-88.

[12] Li, Y., Kannan, D., Garg, K., Gupta, S., Gandhi, K., Jha, P.C. 2018. Business orientation policy and process analysis evaluation for establishing third party providers of reverse logistics services, J. Clean. Prod., 182, 10331047.

[13] Hoang, V.H., Nguyen, T.S. 2019. The effect of logistics service on firm financial performance in textile industry: evidence from Da Nang city Vietnam, in MATEC Web of Conferences, 259, 4002.

[14] Nguyen, G.N.T., Sarker, T. 2018. Sustainable coffee supply chain management: a case study in Buon Me Thuot City, Daklak, Vietnam, Int. J. Corp. Soc. Responsib., 3(1), 1.

[15] Barata, J., Rupino Da Cunha, P., Stal, J. 2018. Mobile supply chain management in the industry 4.0 era: an annotated bibliography and guide for future research, J. Enterp. Inf. Manag., 31(1), 173-192.

[16] Prakash, C., Barua, M.K. 20I5. ntegration of AHP-TOPSIS method for prioritizing the solutions of reverse logistics adoption to overcome its barriers under fuzzy environment, J. Manuf. Syst., 37, 599-615.

[17] Heydari, J., Govindan, K., Jafari, A. 2017. Reverse and closed loop supply chain coordination by considering government role, Transp. Res. Part D Transp. Environ.

[18] Álvarez-SanJaime, Ó., Cantos-Sánchez, P., Moner-Colonques, R., Sempere-Monerris, J.J. 2013. Vertical integration and exclusivities in maritime freight transport, Transp. Res. Part E Logist. Transp. Rev.

[19] Lee, S.W., Song, J.M. 2014. Economic possibilities of shipping though Northern Sea Route, Asian J. Shipp. Logist.

[20] Sudan, R., Clark, P., Henry, B. 2015. Cost and logistics for implementing the American College of Surgeons objective structured clinical examination, Am. J. Surg. 